\title{
GERAKAN PENCERAHAN (AUFKLARUNG) DALAM ISLAM: Menguak Islamisasi Ilmu Pengetahuan Syed Naquib al-Attas
}

\author{
Oleh: \\ Raha Bistara* \\ Universitas Islam Negeri Sunan Kalijaga Yogyakarta \\ rahabistara07@gmail.com
}

\begin{abstract}
This article wants to explain how the concept of Islamization of science as Aufklarung for Muslims. The spread of secularism in the Islamic world has brought Muslims under the dichotomy of the West. They are trapped by Western knowledge which is skeptical on the basis of rationalism and empiricism. This epistemology is not in accordance with the spirit, the scientific spirit of Muslims. Muslims have their own epistemology of knowledge based on the principles of Islamic teachings from the Qur'an and Sunnah and the spirit of divine knowledge. Therefore Sayed Naquib al-Attas developed the concept of Islamization of science as an enlightener (Aufklarung) for Muslims. By using the library research method and using primary sources in the form of the original work of Sayed Muhammad Naquib al-Attas and secondary sources that support this research. The research is expected to answer the concept of Islamization of knowledge as an era of enlightenment (Aufklarung) which was developed by al-Attas. This Islamization becomes the basis of Islamic knowledge that must be disseminated by every individual Muslim, because they are all responsible for Islamic knowledge. Because with this enlightenment movement, Muslims will be independent and find themselves in accordance with the spirit of Islamic principles that do not follow Western knowledge. With the Aufklarung movement, throught the discourse cam develop Muslim personalities so that Muslims can give birth to goodness, Justice, and The strength of faith.
\end{abstract}

Keywords: Syed Naquib al-Attas, Islamization of knowledge, Aufklarung

\section{A. PENDAHULUAN}

Islam sebagai agama yang hanif mengajarkan kepada umatnya mengenai pentingnya ilmu pengetahuan. Daulah Abbasiyah menjadi daulah yang paling mentereng dalam mengembangkan ilmu pengetahuan dan peradaban sehingga disebut sebagai The Golden of Age nya Islam (Wahyuni 2018) Namun, kejayaan ilmu pengetahuan ini hanya bertahan sampai abad ke14. Sesudah itu mereka tertidur pulas 
dalam romantisme masa silam sampai abad ke-19 akhir. Abad ke-19 akhir dan awal abad 20-an menjadi titik tolak awal demi perkembangan kedua dalam Islam.

Kemajuan teknologi yang dialami oleh bangsa-bangsa Barat membuat bangsa Timur mengkiblat kepada bangsa Barat mengenai ilmu pengetahuan dan sains khususnya yang menyebabkan bangsa Timur kehilangan ciri ilmu pengetahuannya yang khas (Bistara 2020) Mereka mengimpor ilmu pengetahuan dari Barat dengan mentah-mentah tanpa adanya filter yang digunakan oleh umat Islam. Hal inilah yang dimanfaatkan oleh bangsa Barat untuk menjajah bangsa Timur baik dari segi ilmu pengetahuan, politik, budaya, dan kolonialisasi.

Kondisi seperti ini sangat lama, sehingga ilmu pengetahuan Islam berada dalam fase terendah dan terbelakang. Ilmu pengetahuan Islam tidak lagi memberikan perspektif masa depan yang cerah bagi umat Islam (Yulianto and Baihaki 2018) Keadaan ini berlaku di seluruh negara Islam, beriringan dengan masa ini, negara Islam menjadi objek jajahan yang dilakukan oleh bangsa Barat, Napolen menjajah Mesir pada tahun 1798 M. Namun ekspedisi ini tidak hanya datang sebagai ekspansi militer, tetapi juga untuk keperluan ilmiah. Kedatangan mereka disambut dengan perlawanan fisik dan intelektual oleh kaum muslim.

Bagi Naquib al-Attas mengenai keruntuhan dan perpecahan kekuatan bangsa muslim membuat masyarakat Islam, terutama reformernya yang memiliki konsep-konsep yang begitu hebat kemudian terabaikan. Kita lihat Ibn Khaldun tentang konsep ummah dan Negara dalam Islam. Sehingga ada usaha untuk mengerahkan kepada pembangunan kembali konsepkonsep tersebut. Dengan demikian perhatian terhadap konsep-konsep individu dan peranan individu dalam membina umat dan mewujudkan negara Islam sudah terabaikan (Syed Muhammad Naquib Al-Attas 1979) Dengan begitu tidak ada perkembangan dalam diri setiap individu Islam dan negaranya, karena mereka semua terkungkung dalam sel yang telah dibuat oleh bangsa lain.

Transformasi keilmuan yang datang dari Barat yang lebih menekankan pada rasionalitas dan mengesampingkan nilai-nilai ilahiah berdampak pada lepasnya nilai teologis pada sains. Sains yang dibangun berlandaskan teologis hanya akan melahirkan ilmuanilmuan yang kering akan nilai spiritualitas dan tercerabutnya sains dari dimensi transendental (Lestari and Salma 2020) Bagi al-Attas ilmu pengetahuan modern yang bersifat sekuler menjadi tantangan tersendiri bagi umat Islam dan transfer ilmu modern ini menjadi biang kebingungan dalam pendidikan Islam.

Peradaban baru yang dibangun oleh bangsa Barat memang memiliki sumbangsih besar terhadap peradaban umat manusia, tetapi di sisi yang lain juga menghilangkan nilai-nilai norma yang sudah berlaku pada umat manusia terutama umat Islam. Hal ini tentu menjadi problematis bagi kemajuan umat Islam sendiri yang 
meyakini adanya kekuatan adikodrati di atas ilmu pengetahuan. Dengan merebaknya ajaran modern yang bersifat sekuler dalam diri umat Islam maka perlu adanya gagasan baru yang menetralisir gagasan modern yang bersifat sekularistik. Gagasan ini dikenal sebagai gagasan "islamisai ilmu" yang dikembangkan oleh Sayed Naquib al-Attas sendiri.

Semangat yang digaungkan oleh al-Attas terobsesi dari masa the Golden of Age nya Islam masa Klasik. Pada tahap ini Islam dikenal sebagai kebangkitan kedua atau disebut sebagai Aufklarung yang dimotori oleh Naquib al-Attas. Melihat epistemologi yang dikembangkan oleh al-Attas berati tantangan terberat umat Islam dalam bidang ilmu pengetahuan. Pengetahuan yang selama ini dikembangkan oleh bangsa Barat hanyalah untuk meracuni umat Islam (Syed Muhammad Naquib al-Attas 1993) Jadi ada semacam gerakan perlawanan yang dipelopori oleh alAttas untuk meruntuhkan hegemoni Barat atas Islam baik dari ilmu pengetahuan maupun kebudayaan.

Dengan begitu penelitian ini bertujuan memberikan pandangan baru terkait gerakan Aufklarung dalam Islam yang berbeda dengan gerakan Aufklarung yang ada di Barat. Melalui ide islamisasi ilmu diharapkan memberikan sebuah wacana keilmuan baru yang sesuai dengan ruh umat Islam yang nantinya akan melahirkan pribadi muslim universal.

\section{B. METODE PENELITIAN}

Dengan menggunakan metode library research (Kaelan 2005) dengan data sekunder beruapa karya asli dari Sayed Muhammad Naquib al-Attas dan data primer sebagai punjang penelitian ini. Melaui pengolahan data ini diharapkan bisa menemukan jawaban atas pertanyaan terkait islamisasi ilmu pengetahuan sebagai Aufklarung dalam peradaban Islam.

\section{HASIL DAN PEMBAHASAN}

\section{Karier Intelektual Syed Naquib al-Attas}

Syed Muhammad Naquib alAttas atau yang sering disebut Naquib al-Attas, salah seorang cendekiawan muslim yang dilahirkan di Indonesia, tepatnya di Bogor Jawa Barat pada tanggal 5 September 1931. Melihat garis silsilah keluarga Naquib al-Attas, ia berdarah biru dari keluarga Sayyid, ayahnya bernama Syed Ali bin Abdullah al-Attas berasal dari Saudi Arabia dengan silsilah keturunan ulama dan ahli tasawuf yang sangat terkenal dari kelompok sayyid (El Hakim and Fahyuni 2020) Sedangkan ibunya bernama Syarifah Raguan al-Idrus berasal dari keturunan kerabat rajaraja pada kerjaan Sunda Sukapura, Jawa Barat.

Latar belakang keluarga yang sedemikian rupa dengan semangat religius yang begitu mendalam, memberikan pengaruh yang sangat kuat terhadap Naquib al-Attas. Pendidikan awal Naquib al-Attas diterima dari keluarga sang ibu yang 
terdapat di Bogor, ia memperoleh ilmu-ilmu keislaman, sedangkan dari keluarga yang ada di Johor memperoleh ilmu sosial humaniora seperti bahasa, sastra, dan kebudayaan Melayu (Wan Mohd Nor Wan Daud 1998). Kedua jenis keilmuan ini yang nanti akan membentuk keilmuan Naquib alAttas dalam perkembangan khazanah intelektual Islam.

Pendidikan al-Attas dimulai sejak berusia 5 tahun saat diajak kedua orang tuannya bermigrasi ke Malaysia. Di sini al-Attas dimasukkan ke Ngee Heng English School, Johor sampai usia 10 tahun (1936-1941) Kemudian pada masa pendudukan Jepang, melihat situasi yang kurang menguntungkan, alAttas dan keluarganya kembali ke Jawa Barat. Di sini ia meneruskan pendidikannya di Madrasah al-Urwah al-Wutsqa, Sukabumi pada tahun 1941-1945, sebuah lembaga pendidikan yang menggunakan bahasa Arab sebagai pengantar.

Setelah Perang Dunia II usai, alAttas dan keluarganya kembali ke Johor untuk menempuh pendidikan lanjutan. Pertama di Bukit Zahrah School, kemudian di English College (1946-1951) Pada paruh waktu ini, al-Attas mendaftarkan diri sebagai tentara Nasional Malaysia. Namun, tidak lama setelah Malaysia merdeka pada tahun 1957, al-Attas mengundurkan diri dari dunia militer dan melanjutkan pendidikannya, minatnya yang sangat mendalam dalam dunia ilmu pengetahuan telah membawanya pada Universitas Malaya, Kuala Lumpur selama dua tahun pada Fakultas Kajian Ilmu-ilmu
Sosial (Social Sciences Studies) (Muslem 2019)

Selama studi S1, al-Attas telah menulis dua buku penting yakni Rangkaian Ruba'iyat, dan Some Aspects of Sufism as Understood and Practised Among the Malays. Buku kedua ini dianggap buku paling berharga dan penting bagi pemerintahan Kanada, sehingga melalui Kanada Council Felloship, memberikannya beasiswa untuk belajar di Institute of Islamic Studies, Universitas McGill, Monreal Canada (1960-1962) Dari universitas ini alAttas memperoleh gelar Master of Arts (M.A) setelah tesisnya berjudul Raniri and the Wujudiyah of 17 Century Acheh, lulus dengan nilai yang memuaskan (Aidil Farina Omar dan Azmul Fahimi Kamaruzaman 2020)

Setahun kemudian al-Attas pindah ke School of Oriental and African Studies di Universitas London (1963-1965) untuk meneruskan pendidikan doktoralnya. Dari sini ia memperoleh gelar Doctor of Philosophy (Ph. D) dengan predicat Cumlaude dalam bidang Filsafat Islam dan Kesusastraan Melayu Islam setelah mempertahankan disertasinya yang berjudul The Mysticism of Hamzah Fansuri.

Setelah menamatkan pendidikannya di London, al-Attas kembali ke almamaternya dulu, yaitu Universitas Malaya. Di sini ia mulai menunjukkan kehebatan dan kecemerlangannya, sehingga ia dilantik menjadi Ketua Jurusan Sastra pada Fakultas Kajian Melayu. Tidak 
lama kemudian naik menjadi Dekan Fakultas Sastra dan menjadi salah satu pendiri senior Univesritas Kebangsaan Malaysia (UKM) dan juga mendirikan sekaligus emnjadi rektor International Institute of Islamic Thought and Civilization (ISTAC) di Malaysia (Wan Mohd Nor Wan Daud 1998)

\section{Islamisasi Ilmu Pengetahuan Syed Naquib al-Attas}

Merebaknya paham sekularisme di dunia Timur Islam, menyebabkan umat Islam kehilangan arah dan tujuan dalam ilmu pengetahuan dan peradaban. Mereka (umat Islam) menerima dan menelan mentahmentah apa yang datangnya dari Barat tanpa ada filterasi pemahaman dari mereka. Semangat pengetahuan yang dikembangkan bukan semangat ciri dari pengetahuan Islam, melainkan semangat mengadopsi dari Barat yang menghilangankan nilai-nilai religius di dalamnya. Maka al-Attas dengan sangat lantang menentang semua bentuk keilmuan yang datangnya dari Barat.

Naquib al-Attas menjelaskan bahwa pengetahuan yang datang dari Barat mengangkat keraguan dan pendugaan ke derajat ilmiah dalam hal metodologi. Artinya, keraguraguan dijadikan sebagai epistemologi yang cukup baik dan istimewa dalam mendapatkan pengetahuan (Syed Muhammad Naquib al-Attas 1993) Tambahnya, ilmu pengetahuan Barat tidak dibangun di atas landasan wahyu dan kepercayaan agama. Tetapi dibangun atas tradisi budaya yang diperkuat dengan spekulasi filosofis yang terkait dengan kehidupan sekuler yang menjadikan manusia sebagai makhluk rasional.

Peradaban Barat juga mengambil semangat rasionalisme dalam Islam, namun pengetahuan dan semangat rasional serta ilmiah ketika di Barat dibentuk kembali sesuai dengan kebudayaan yang ada di Barat. Peleburan semacam ini kemudian pada akhirnya akan melahirkan karakter yang dualistik dalam pandangan dunia serta nilai-nilai kebudayaan dan peradaban Barat (Ziauddin Zardar 1998) Ada semacam penghilangan nilai-nilai religius setelah dilakukan purifikasi yang dilakukan oleh orang Barat terhadap rasionalisme yang diimpor dari Islam. Mereka dengan semangat naturalisme, rasionalisme, dan empirisme dengan sengaja menyisihkan nilai religius yang dianggap tidak membawa perubahan zaman.

Dengan demikian pengetahuan Barat tidak bersifat netral melainkan telah dicampuri dan cemari oleh watak dan peradaban Barat yang dualistik (Muslem 2019) Artinya bahwa dari wolrd-view yang dualistik, konsep kebenaran Barat kemudian tidak dirumuskan di atas pengetahuan yang diwahyukan atau kepercayaan keagamaan, tetapi di atas tradisi kebudayaan yang diperkuat dengan dasar-dasar filosofis dan renungan-renungan yang bertalian dengan kehidupan duniawi yang berpusat pada manusia sebagai makhluk rasional. 
Sekali lagi al-Attas menandaskan bahwa epistemologi yang dibangun oleh Barat menggaungkan skeptisisme yang menyebabkan ketegangan batin, yang pada gilirannya membangkitkan keinginan tak pernah terputuskan untuk mencari dan memulai suatu perjalanan dalam mencari suatu penemuan dan penemuan yang lainnya. Sedangkan bagi al-Attas menjelaskan kebenaran itu hanya bisa diperoleh melalui sebuah hidayah. Bagi umat Islam hidayah adalah suatu kebenaran yang mutlak ketika ia mencari dan mencari sutau kebenaran di muka bumi ini, tanpa hidayah kebenaran itu bersifat ambigu dan tidak bisa dipertanggungjawabkan.

Menanggapi kondisi semacam demikian yang kian merebak pada umat Islam Syed Muhammad Naquib al-Attas menghendaki adanya islamisasi ilmu. Isu ini pada mulanya digagas oleh al-Attas pada konferensi dunia pertama pendidikan Islam di Makkah pada tahun 1977 M. Pada saat itu al-Attas menjelaskan panjang lebar pada konferensi dunia kedua di Islamabad. Secara umum pengertian islamisasi ilmu diterangkan dengan gamblang sebagai berikut:

Pembebasan manusia dari tardisi magis, mitologis, animitis, kulturnasonal (yang bertentangan dengan Islam) dan dari belenggu paham sekuler terhadap pemikiran dan bahasa juga pembebasan dari kontrol dorongan fisiknya yang cenderung sekuler dan tidak adil terhadap hakikat diri atau jiwanya, sebab manusia dalam wujud fisiknya cenderung lupa terhadap hakikat dirinya yang sebenarnya menjadi bodoh akan tujuan yang sebenarnya, dan berbuat tidak adil terhadapnya. Islamisasi adalah proses menuju bentuk asalnya yang tidak sekuat proses evlousi dan devolusi(Wan Mohd Nor Wan Daud 1998)

Secara epistemologi, islamisasi ilmu berkaitan dengan pembebasan akal mendasari dari keraguan (syakk), prasangka (zhann), dan argumentasi kosong menuju pencapaian keyakinan (yakin) dan kebenaran (haq) mengenai realitasrealitas spiritual, penalaran dan material. Proses pembebasan ini awal mulanya bergantung pada pengetahuan, tetapi pada akhirnya selalu dibangun atas suatu ilmu pengetahuan khusus (ma'rifah). Bentuk ilmu ini melibatkan fardhu ain dan fardhu kifayah. Maka kaitannya dengan ilmu pengetahuan kontemporer islamisasi berati pembebasan ilmu pengetahuan dari penafsiran yang berdasarkan ideologi, makna-makna, dan ungkapanungkapan yang sekuler.

Dengan pandangan seperti ini, maka realitas yang sesungguhnya adalah Tuhan. Dari Tuhan melimpah wujud-wujud, dan karena merupakan limpahan-Nya, semuanya mengandung aspek ilahiah (Soleh 2011). Namun prosentasi ilahiah ini berbeda-beda sesuai dengan hierarkinya, semakin jauh dari pusat hierarki berarti semakin kecilnya sifat ilahiah pada suatu maujud. Ilmu pengetahuan yang dibangun atas fondasi epistemologi yang diagungkan Barat tidak memiliki hierarki keilmuan menuju ke Tuhan, hal ini yang semestinya tidak dipakai oleh umat Islam karena umat Islam 
memiliki pola epistemologinya sendiri.

Islamisasi yang digaungkan oleh al-Attas adalah suatu istilah yang membawa sesuatu ke dalam Islam atau membuatnya dan menjadikannya Islam sesuai dengan ruh dari epistemologi Islam. Istilah ini bukan berarti Islam tidak bersifat universal, melainkan lebih berati bahwa di luar Islam masih banyak berbagai macam hal yang jauh dari nilai-nilai keislaman itu sendiri yang tidak pas dipakai oleh umat Islam. Justru istilah islamisasi merupakan gambaran universal sebagai langkah atau suatu usaha memahamkan segala sesuatu dengan kerangka Islam (islamic framework) (Dody Irawan 2019) Oleh sebab itu pemahaman akan sesuatu yang jauh dari nilai-nilai keislaman tersebut dibutuhkan adanya suatu formula baru untuk menetralisasi yang tidak sesuai dengan kaidah umat Islam, hanya satu solusinya yakni islamisasi ilmu.

Seperti yang telah dijelaskan oleh Wan Mohd Nor Wan Daud di atas al-Attas juga menjelaskan definisi islamisasi ilmu diperoleh dari pemahaman terhadap islamisasi secara umum, yaitu suatu upaya pembebasan manusia dari tradisi mythology, magical, national cultural tradition, animism, dan secularism (Syed Muhammad Naquib al-Attas 1993) Al-Attas juga memaknai islamisasi sebagai suatu proses hijrahnya manusia dari tradisi-tradisi tersebut di atas, meskipun manusia mempunyai komponen jasmani dan rohani sekaligus, namun pembebasan itu lebih menujukan pada rohaniah, sebab manusia yang demikianlah disebut sebagai manusia sejati yang semua tindakannya dilakukan dengan dasar penuh akan nilai dan makna. Al-Attas juga menambahkan bahwa ada dua makan islamisasi, yaitu suatu pikiran dari pengaruh eksternal dan pikiran dari dorongan internal.

Secara umum, islamisasi ilmu pengetahuan tersebut dimaksudkan untuk memberikan respons positif terhadap ilmu pengetahuan modern yang bersifat sekularistik dalam model ilmu pengetahuan baru yang secara integral tanpa adanya pemisah di antara keduanya (Sholeh 2017) Proses pengintegrasian antara ilmu pengetahuan yang berkembang di dunia Barat dengan konsep Islam dan ilmu pengetahuan yang berkembang di dunia Timur Islam. Dengan adanya pengintegrasian ilmu ini diharapkan umat Islam tidak kehilangan akarnya sebagai umat yang meyakini ada kekuatan ilahiah yang mempengaruhi pola kehidupan mereka baik dari segi ilmu pengetahuan maupun kebudayaan.

Dengan begitu konsep islamisasi ilmu bukan hanya sekedar konsep teoritis, namun juga praktis. Dalam prosesnya, islamisasi ilmu pengetahuan memiliki empat kepentingan yang saling berkaitan, kepentingan akidah, kepentingan kemanusiaan, kepentingan peradaban, dan kepentingan ilmiah (Siregar 2013) Sehingga akidahlah yang menjadi kepentingan utama dalam proyek islamisasi ilmu pengetahuan, bukan hanya kepentingan ilmiah. Islamisasi ilmu merujuk kepada proses membina suatu metodologi untuk berurusan dengan ilmu dan sumbernya. 


\section{Proses Islamisasi Ilmu Pengetahuan}

Proses islamisasi ilmu pengetahuan ini akan dilaksanakan ketika proses ilmu pengetahuan ini dijalankan dengan beberapa prinsip pokok berupa tauhid, syariah, dan akhlak. Ketiga prinsip tersebut menjadi dasar bagi ilmu pengetahuan yang ada. Tanpa ketiga landasan tersebut ilmu pengetahuan dalam Islam mustahil bisa berkembang secara baik bahkan mustahil terjadi dalam lingkup kajian ilmu pengetahuan di dalam Islam. Islamisasi ilmu pengetahuan ini bisa dilakukan dengan dua cara yakni: pertama, dengan cara mengislamkan ilmu-ilmu pengetahuan yang ada maupun sedang berkembang. Kedua, dengan cara mengilmukan Islam.

Naquib al-Attas berpendapat proses islamisasi ilmu bisa dilakukan dengan dua cara, pertama, melakukan proses pemisahan elemen-elemen dan konsep-konsep kunci yang membentuk kebudayaan dan peradaban Barat. Dalam artian menjauhkan diri dari segala sesuatu yang menjadi peluang terjadinya budaya yang menimbulkan suatu peradaban yang dihasilkan oleh orang-orang Barat. Misalnya kita ambil saja bahasa. Bahasa di sini memberi peluang terjadinya budaya yang menjadikan budaya Barat berkembang secara masif dalam diri umat Islam. Mulai dari pengguna bahasa sampai memperlakukan bahasa tersebut bisa menjadi pijakan awal umat Islam kehilangan jati dirinya sebagai insan yang religius.
Kedua, bagi al-Attas adalah memasukkan elemen-elemen Islam dan konsep-konsep kunci ke dalam setiap cabang ilmu pengetahuan masih yang relevan. Dalam arti konsep kedua ini al-Attas menidaklanjuti konsep yang pertama yakni dengan memasukkan nilai-nilai Islam dalam unsur-unsur ilmu pengetahuan tersebut. Dengan begitu elemen yang ada dalam Islam dimasukkan ke dalam ilmu pengetahuan yang di bawa dari Barat supaya ilmu tersebut netral dari unsur-unsur yang meninggalkan sistem religius. Misalkan salah satunya memasukan unsur metafisika di dalam ilmu pengetahuan. Metafisika menjadi dasar yang begitu penting dalam membentuk pola sains yang diinginkan oleh umat Islam(Raha Bistara 2020)

Dengan kedua proses yang dicanangkan oleh Nauqib al-Attas, maka seyogyanya umat muslim yang menghadapi guncangan sekularisme yang begitu masif harus mengantisipasi gerakan itu. Umat Islam harus melakukan langkah dalam rangka merealisasikan islamisasi ilmu pengetahuan dalam krisis masyarakat modern. Umat Islam harus menguasai dan mahir dalam disiplin ilmu pengetahuan modern yang sedang berkembang baik dari segi prinsip, konsep, metodologi, masalah, dan tema. Hal ini dianggap penting supaya umat Islam bisa menemukan konsep baru yang berpegang dalam prinsip tauhid (Alwi 2017)

Umat Islam juga harus menguasai warisan Islam itu sendiri supaya bisa menangkis teori-teori 
yang dikembangkan oleh Barat. Gagasan islamisasi ilmu pengetahuan tidak bermakna apabila tidak dikaitkan dengan warisan Islam yang menyumbangkan ilmu pengetahuan yang sangat besar. Namun dengan demikian sumbangan para intelektual Islam Klasik tentang disiplin ilmu pengetahuan modern tidak mudah diperoleh, dibaca, dipahami, oleh seorang intelektual muslim saat ini dengan alasan ilmu pengetahuan modern tidak terdapat padanannya dalam khazanah intelektual Islam dan para sarjana muslim tidak memiliki waktu atau usaha untuk meneliti semua khazanah warisan Islam yang amat kaya dan luas.

Sebenarnya banyak konsep yang harus dilakukan umat Islam pada saat ini dalam mengimplementasikan islamisasi ilmu yang digaungkan oleh Naquib al-Attas. Tanpa adanya tindakan yang dilakukan oleh umat Islam sendiri mustahil konsep yang dicanangkan oleh Naquib bisa berjalan dengan baik di tataran umat Islam. meski gagasan ini menuai banyak pro dan kontranya, tapi ini bisa disebut sebagai gerakan pencerahan kedua dalam umat Islam atau disebut sebagai gerakan Aufklarung dalam dunia Islam.

\section{Islamisasi Ilmu sebagai Gerakan Aufklarung dalam Islam}

Pada abad ke-18 muncullah suatu peradaban baru yang memang telah berakar pada Rennaissance serta yang mewujudkan buah pahit dari rasionalisme dan empirisme. Abad ke-18 disebut sebagai zaman pencerahan (Aufklarung). Menurut
Immanuel Kant zaman Pencerahan adalah zaman manusia keluar dari keadaan tidak akil balik, karena kesalahan yang dibuat oleh manusia itu sendiri. Kesalahan itu terletak pada manusia yang tidak mau memanfaatkan akalnya secara baik.

Memang ada perbedaan yang mencolok antara Renaissance dengan Aufklarung yakni pada Rennaissance membatasi diri pada usaha pada menafsirkan baru terhadap kenyataan dunia dan rohani, yaitu kenyataan mengenai manusia, dunia, dan Allah. Akan tetapi pada abad ke-18 atau masa pencerahan Aufklarung menganggap dirinya sebagai tugas seorang khalifah untuk mengkritisi segala yang ada, baik di dalam negara maupun di dalam masyarakat, baik bidang ekonomi, agama, pengajar, dan ilmu pengetahuan (Harun Hadiwijoyo 2016)

Gagasan islamisasi ilmu pengetahuan adalah gagas Pencerahan (Aufklarung) yang terjadi di tubuh umat Islam. ini adalah gerakan kedua yang dilakukan oleh cendekiawan muslim yang resah atas gerakan sekularisme yang dilakukan oleh bangsa Barat terhadap bangsa Timur Islam. Pada periode pertama gerakan perlawanan yang dilakukan oleh bangsa Timur dilakukan melalui gerakan pembaharuan yang digaungkan oleh Jamaluddin alAfghani dan murid-muridnya. Gagasan al-Ijtihad wa al-Jihad yang digaungkan oleh al-Afghani adalah gagasan dekonstruksi dari dalam dan gerakan perlawanan dari luar yang harus dilakukan oleh umat Islam supaya tidak selalu terkungkung di bawah bangsa Barat. 
Perlawanan yang dilakukan oleh al-Afghani atas hegemoni Barat bukan hanya perlawanan dari segi ilmu pengetahuan, melainkan juga pada kekuatan politik dengan secara menyatukan umat Islam di bawah panji Pan-Islamisme. Ikatan persaudaraan yang mengatasnamakan agama inilah yang hendak diperjuangkan dalam sebuah ide, gagasan, dan aksinya. Dengan begitu berdirinya imperium Islam dijadikan sebagai kiblat peradaban dunia (Andi Saputra 2018) Meskipun begitu gerakan yang digaungkan oleh alAfghani tidak ingin mendirikan politik Khilafah Islamiyah karena itu sulit untuk diciptakan dalam geopolitik umat Islam (Albert Hourani 2004) Gerakan ini adalah suatu gerakan perlawanan pada masa awal Rennaissance Islam yang sudah sejak lama ditunggu oleh umat Islam di seluruh dunia.

Setelah kelompok pertama masa pembaharuan Islam selesai muncul saya anggap sebagai masa Pencerahan (Aufklarung) dalam Islam yang dipelopori oleh Syed Nauib al-Attas yang nanti dilanjutkan oleh cendekiawan muslim yang lain. Masa pencerahan ini seperti yang telah bahas di atas hampir semua aspek digagas oleh pemikir Islam baik agama, kebudayaan, ekonomi, dan ilmu pengetahuan. Gagasan Islamisasi yang digaungkan oleh alAttas adalah suatu pencerahan bagi umat Islam yang selama ini masih terhegemoni gagasan sekularisme yang digalakan oleh Barat.

Menilik dari aspek sejarah Aufklarung yang terjadi di Barat yakni membuat pencerahan dalam segala lini aspek kehidupan terutama ilmu pengetahuan. Gagas al-Attas juga mencakup segala aspek kehidupan, permasalahan dan tujuan akhir setiap muslim baik individu maupun secara keseluruhan (Garwan 2019) Ini adalah suatu tanggung jawab yang harus dilakukan oleh setiap individu muslim, mereka harus menggalakan gerakan islamisasi ilmu yag digaungkan oleh al-Attas supaya zaman Pencerahan ini terjadi secara menyeluruh dalam bangsa Timur Islam.

Sebagai khalifah di muka bumi, manusia memiliki unsur utama yaitu organ fisik dan jiwa (nafs), dimensi jiwa ini lebih tinggi dari sekedar dimensi fisik karena jiwa merupakan bagian metafisik (Nuryanti and Hakim 2020) Metafisik ini adalah salah unsur yang digalakan dalam masa Aufklarung dan ini salah satu unsur yang digalakan oleh Naquib alAttas. Baginya metafisika menjadi unsur terpenting dalam islamisasi ilmu pengetahuan dan itu yang tidak ada dalam epistemologi Barat yang bersifat rasionalis dan empiris. Ini adalah suatu perlawanan terhadap paradigma Barat yang sudah menyebar secara akut dalam diri umat Islam.

\section{Implikasi Gerakan Aufklarung dalam Islam dalam Wacana Islamisasi Ilmu}

Setelah merebaknya wacana sekularisme yang melanda umat Islam dengan obsesi yang begitu menggebu dengan berujung lepasnya semangat berilmu dari nilai-nilai transenden keagamaan. Akhirnya 
tibalah saatnya umat Islam harus kembali tercerahkan dengan semangat yang mengkantar-kantar melalui gagasan "Islamisasi Ilmu". Seperti yang kita pahami gerakan sekularisme yang memisahkan ilmu dari agama adalah gerakan salah kaprah. Karena masyarakat Timur Islam tidak bisa jauh bahkan dipisahkan dari unsur-unsur religius.

Zuhairini menandaskan bahwa agama yang dimiliki oleh bangsa Timur Islam adalah nilai-nilai panutan yang memberikan pedoman pada tingkah laku manusia dan pandangan hidupnya. Sedangkan ilmu adalah suatu hasil yang dicapai berkat kemampuan yang diberikan oleh Tuhan kepada makhluknya (Zuhairini 1995) Dengan begitu ilmu dan agama adalah dua unsur yang bersifat transendental tidak bisa dipisahkan satu sama yang lain. Karena ilmu pada hakikatnya bukan ilmu untuk ilmu melainkan ilmu untuk kemaslahatan bersama terutama bagi umat Islam.

Islamisasi ilmu yang digaungkan oleh al-Attas sebagai wacana pencerahan telah berhasil mengislamisasikan ilmu pengetahuan yang telah didominasi oleh unsurunsur Barat yang itu bertentangan dengan ajaran Islam. Wacana Aufklarung melalui islamisasi ilmu juga ternyata membebaskan umat Islam dari cengkeraman ilmu yang sudah tercemarkan, menyesatkan, dan menimbulkan kekeliruan dalam discourse keislaman. Yang begitu penting adalah dengan gerakan Aufklarung melalui wacana islamisasi ilmu dapat mengembangkan kepribadian muslim sehingga umat muslim bisa melahirkan kebaikan, keadilan, dan kekuatan iman.

Implikasi yang begitu jelas dan nyata adalah mencerahkan dalam dunia pendidikan Islam. Naquib alAttas selalu menggaungkan bahwa pendidikan Islam yang tetap menggunakan kata ta'dib. Ta'dib menjadi konsep yang begitu komprehensif dalam sistem pendidikan nasional dan ini adalah jawaban atas problem yang selama ini melanda sistem pendidikan umat Islam. Ta'dib memiliki nilai-nilai yang begitu epik, nilai itu antara lain adl, hikmah, dan amal. Ketiga nilai yang ada dalam konsep ta'dib kesemuanya adalah konsep terapan yang dibutuhkan umat muslim untuk keluar dari cengkeraman bangsa Barat.

Jika konsep ini diterapkan dalam dunia pendidikan Islam secara nasional, maka besar kemungkinan tujuan pendidikan secara nasional akan tercapai dan umat Islam akan keluar dari dikotomi pendidikan yang selama ini hanya mengikuti pola yang dikembangkan oleh bangsa Barat yang itu tidak sesuai dengan nilainilai keislaman yang dimiliki oleh bangsa Timur. Menurut Albar Adetary Hasibuan tidak ada keraguan lagi bangsa Indonesia khususnya menggunakan konsep ta'dib yang digaungkan oleh Naquib al-Attas sebagai masa pencerahan (Hasibuan 2015) Konsep ta'dib sebetulnya sudah diterapkan dalam kerangka pendidikan tertua yang ada di Nusantara yakni dalam dunia pondok pesantren. Maka tidak diragukan lagi konsep ta'dib adalah konsep 
Aufklarung dalam sistem pendidikan Islam.

Gagasan Naquib ini diharapkan juga bisa menghantarkan manusia mencapai puncaknya menjadi pribadi yang agung yakni berupa Insan alKamil. Karena ta'dib ini yang nantinya akan membentuk manusia dalam mengembangkan potensinya baik lahir maupun batin supaya menjadi muslim yang seutuhnya (Haidar Putra Daulay 2014) Pada hakikatnya tujuan pendidikan menjadikan manusia taat kepada Allah dalam rangka melaksanakan fungsinya sebagai khalifatulallah fil ard yang selalu menyampaikan pesan-pesan kebaikan dan perdamaian (Abudin Nata 1997)

\section{KESIMPULAN}

Sekularisme yang digalakan oleh bangsa Barat atas dunia Islam berdampak sangat signifikan bagi perkembangan umat Islam. Umat Islam menjadi umat yang taqlid terhadap ilmu pengetahuan yang datang dari Barat, mereka tercerabut dari akarnya sebagai bangsa muslim yang memiliki citra percaya kepada Allah Swt. Sedangkan Barat tidak memiliki nilai kepercayaan tersebut, secara otomatis epistemologi yang dibangun oleh Barat adalah

\section{Daftar Kepustakaan}

Abudin Nata. 1997. Filsafat Pendidikan Islam. Jakarta: Logos Wacana Ilmu.

Aidil Farina Omar dan Azmul Fahimi Kamaruzaman. 2020. epistemologi skeptis atas praduga dari rasionalisme dan empirisme.

Epistemologi Barat yang menjalar di dunia Islam membuat cendekiawan muslim bangkit melawan ketertindasan yang dilakukan oleh bangsa Barat baik dari sisi kebudayaan ataupun ilmu pengetahuan. Salah satunya adalah Sayed Muhammad Naquib al-Attas. Al-Attas merasa gusar dengan apa yang dilakukan oleh bangsa Barat atas umat Islam, maka gagasan Pencerahan (Aufklarung) yang digalakan oleh al-Attas adalah islamisasi ilmu pengetahuan.

Islamisasi ilmu ini sebagai gagasan pencerahan yang dilakukan oleh al-Attas sebagai bentuk perlawanan terhadap Barat. Islamisasi ini mencoba mengislamkan ilmuilmu yang belum tersentuh dengan nilai-nilai keislaman. Dengan menggunakan konsep islamisasi secara nasional, besar kemungkinan tujuan pendidikan Islam akan tercapai dengan baik. Umat Islam tidak perlu lagi mengekor dengan model pendidikan yang dilakukan di Barat yang bersifat sekuler. Ketika pendidikan ini ditancapkan pada kediri-an umat Islam, maka kepribadian umat muslim akan melahirkan kebaikan, keadilan, dan kekuatan iman.

\author{
"KONTEKS \\ HISTORIOGRAFI \\ SYEDMUHAMMAD \\ NAQUIB AL-ATTAS." \\ Jurnal Tuah 1: 24-40.
}


Albert Hourani. 2004. Pemikiran LIberal Di Dunia Arab. Bandung: Mizan.

Alwi, Marjani. 2017. "Islamisasi Ilmu Pengetahuan Kontribusi Dalam Mengatasi Krisis Masyarakat Modern." Inspiratif Pendidikan 6 (2): 259. https://doi.org/10.24252/ip.v6i 2.5230 .

ANDI SAPUTRA. 2018. "PANISLAMISME DAN KEBANGKITAN ISLAM: REFLEKSI FILSAFAT SOSIAL-POLITIK JAMALUDDIN AFGHANI" 14 (2): 54-58.

Bistara, Raha. 2020. "Islam Dan Sains Menurut Sayyed Nasr Nasr." Prosiding Konferensi Integrasi Interkoneksi Islam Dan Sains 2: 113-17.

Dody Irawan. 2019. "Rekonstruksi Islamisasi Sains Sebagai Langkah Awal Islamisasi Ilmu: Pemikiran Syed Muhammad Naquib Al-Attas" 10 (1): 1-17.

Garwan, Muhammad Sakti. 2019. "Urgensi Islamisasi Ilmu Syed Naquib Al-Attas Dalam Upaya Deskonstruksi Ilmu Hermeneutika Al-Qur'an." Substantia: Jurnal Ilmu-Ilmu Ushuluddin $21 \quad$ (2): 125 . https://doi.org/10.22373/subst antia.v21i2.5668.

Haidar Putra Daulay. 2014. Pendidikan Islam Dalam Perspektif Filsafat. Jakarta: Kencana.
Hakim, Mohammad David El, and Eni Fariyatul Fahyuni. 2020. "Pendidikan Islam Dalam Perspektif Syed Naquib AlAttas Dan Relevansinya Bagi Pengembangan Pendidikan Islam Di Indonesia." Islamika 2 (1): 46-62. https://doi.org/10.36088/islam ika.v2i1.494.

Harun Hadiwijoyo. 2016. Sari Sejarah Filsafat Barat 2. Yogyakarta: Kanisius.

Hasibuan, Albar Adetary. 2015. Filsafat Pendidikan Islam. Malang: UIN Maliki Press.

Kaelan. 2005. Metode Penelitian Kualitatif Bidang Filsafat. Yogyakarta: paradigma.

Lestari, Puspita Ayu, and Ria Fauziah Salma. 2020. "Konsep Pembelajaran Fakultas Kesehatan Universitas Darussalam Gontor: Implementasi Konsep Islamisasi." Prosiding Konferensi Integrasi Interkoneksi Islam Dan Sains 2: 483-92.

$$
\begin{array}{lr}
\text { Muslem. } 2019 . & \text { "KONSEP } \\
\text { ISLAMISASI } & \text { ILMU } \\
\text { PENGETAHUAN } & \text { DAN } \\
\text { PENERAPANNYA DALAM } \\
\text { PENDIDIKAN ISLAM (Studi } \\
\text { Pemikiran Syed Muhammad } \\
\text { Naquib Al-Attas)." } & \text { Tazkiya } \\
\text { Jurnal Pendidikan Islam VIII } \\
\text { (2): 43-66. } \\
\text { Nuryanti, Makhfira, and Lukman } \\
\text { Hakim. 2020. "Pemikiran } \\
\text { Islam Modern r Syed } \\
\text { Muhammad Naquib Al- }
\end{array}
$$


Attas." Substantia: Jurnal Ilmu-Ilmu Ushuluddin 22 (1): 73. https://doi.org/10.22373/subst antia.v22i1.5531.

Raha Bistara. 2020. "Polemik Agamawan Dan Saintis Seputar Covid-19: Menilik Gagasan Integrasi Agama Dan Sains Perspektif Mehdi Golshani." DINIKA Academic Journal of Islamic Studies 5 (2): 263-86. https://doi.org/10.36548/jisma c. 2020.4 .

Sholeh, Sholeh. 2017. "Islamisasi Ilmu Pengetahuan (Konsep Pemikiran Ismail Raji AlFaruqi Dan Syed Muhammad Naquib Al-Attas)." AlHikmah: Jurnal Agama Dan Ilmu Pengetahuan 14 (2): 209-21. https://doi.org/10.25299/alhikmah:jaip.2017.vol14(2).10 29.

Siregar, Abu Bakar Adenan. 2013. "Islamisasi Ilmu Pengetahuan." Edukasia Islamika 11 (2): 91-100.

Soleh, A. Khudori. 2011. "Pemikiran Syed Muhammad Naquib AlAttas Tentang Islamisasi Bahasa Sebagai Langkah Awal Islamisasi Sains." LiNGUA: Jurnal Ilmu Bahasa Dan Sastra 5 (1). https://doi.org/10.18860/ling.v 5i1.609.
Syed, and Muhammad Naquib AlAttas. 1979. Aims and Objectives of Islamic Education. Jeddah: Hodder And Stoughton,King Abdul Azis University.

Syed Muhammad Naquib al-Attas. 1993. Islam and Secularism. Kuala Lumpur: International Institute of Islamic Thought and Civilization (ISTAC).

Wahyuni, Fitri. 2018. "Islamisasi Ilmu Pengetahuan ( Upaya Mengurai Dikotomi Ilmu Pengetahuan Dalam Islam )." Qalamuna 10 (2): 1-12.

Wan Mohd Nor Wan Daud. 1998. Filsafat Dan Praktik Pendidikan Islam Syed $M$. Naquib Al-Attas. Edited by Hamid and Fahmy Dkk. Bandung: Mizan.

Yulianto, Rahmad, and Achmad Baihaki. 2018. "Islamisasi Ilmu Pengetahuan Dalam Perspektif Syed Muhammad Naquib Al-Attas." AlHikmah: Jurnal Studi AgamaAgama 4 (1): 1-19. file:///C:/Users/User/Downloa ds/fvm939e.pdf.

Ziauddin Zardar. 1998. Jihad Intelektual. Edited by Priyono. Surabaya: Risalah Gusti.

Zuhairini. 1995. Filsafat Pendidikan Islam. Jakarta: Bumi Aksara. 